\title{
The Role of Fasting Dalailul Qur'an in Shaping Shoim's Personality : Study at Pesantren Bustanu Usysyaqil Qur'an Gading, Semarang Regency
}

\author{
Aufa Abdillah \\ State Institute for Islamic Studies, Salatiga, Indonesia \\ aufalovinskova@gmail.com
}

\begin{abstract}
Fasting dalail Qur'an is a practice carried out by santri at BUQ Gading Islamic Boarding School, which is a special takhfidz al-Qur'an. Fasting is carried out for one year with a qomariyah count and the performers are obliged to complete one juz (chapter) in one day. Santri BUQ are strongly encouraged to practice fasting as a form of riyadhoh fasting so that santri have a personality that is able to control things that are harmful, not useful, and things that are prohibited by religion. The research method used in this study is descriptive qualitative with a phenomenological approach. The results of the study show that santri who practice fasting in the Qur'an are able to form a shoim personality, that is able to control themselves well so as not to do actions, words and attitudes that are detrimental to both themselves and others.
\end{abstract}

Keywords: Santri, Dalail Qur'an Fasting, Shoim Personality

\begin{abstract}
Abstrak
Puasa dalail Qur'an merupakan sebuah amalan yang dilaksanakan santri di Pondok Pesantren BUQ gading, yang merupakan pondok khusus takhfidz alquran. Puasa dilaksanakan satu tahun hitungan qomariyah dan pelaku amalan wajib menghatamkan satu juz dalam satu hari. Para santri BUQ dianjurkan dengan sangat untuk mengamalkan puasa tersebut sebagai bentuk riyadhoh agar santri mempunyai kepribadian yang mampu mengendalikan hal-hal yang merugikan, tidak bermanfaat, dan serta hal-hal dilarang agama. Metode penelitian yang digunakan dalam studi ini adalah kualitatif deskriptif dengan pendekatan fenomenologi. Hasil penelitian menunjukkan bahwa santri yang mengamalkan puasa dalail Qur'an mampu membentuk kepribadian shoim, yaitu kepribadian yang mampu mengendalikan diri dengan baik untuk tidak melakukan perbuatan, perkataan dan sikap yang merugikan baik diri sendiri maupun orang lain.
\end{abstract}

Kata Kunci: Santri, Puasa dalail Qur'an, Kepribadian Shoim 
JNUS: Journal of Nahdlatul Ulama Studies, Vol. 2, No. 2, Juli 2021: 151-162

\section{INTRODUCTION}

Traditional (salaf) Islamic Boarding Schools are the oldest Islamic educational institutions in Indonesia, which are still preserved by NU and the hallmark of NU's traditional education. The islamic boarding school was established immediately after Islam first entered the archipelago in the first century of Hijriyah, coming directly from Arabia during the caliphate of Usman bin Affan, where he sent a delegation of Sa'ad Bin Abi Waqosh to China which was on a journey before reaching China, Sa'ad visited Indonesia. The spread of Islam in Indonesia is carried out peacefully by not changing existing customs and culture, but through cultural acculturation, so that Islam is well-received in the archipelago with a distinctive archipelago style which is certainly different from Middle East. Although differently packaged, but the essence of the teachings is the same. The existence of pesantren (islamic boarding) cannot be separated from kyai and santri, symbols of teachers and students. With the existence of pesantren, a cleric (kyai) can form his cadre and successor more intensively. From the first Islamic boarding school founded by Sunan Ampel in Surabaya, several scholars were struggle to continue the spreading Islam and finally lots of pesantren were still exist up to now which maintain their style and characteristics, namely the traditional NU pesantren.

Pesantren is not only developing as an institution that only teaches religious knowledge, but also plays an important role in the sustainability of communities which maintains traditional existence as a face for the authenticity of Indonesian culture with an indigenous pattern, which is able to reconstruct the chaotic culture increasingly hitting the ideological heart of Indonesian society. So, in its development, the role of pesantren is very important in shaping the character of santri, which will later become applicable values in society. Up to now, Islamic boarding schools still exist and even get the sympathy and interest in the wider community during the era of globalization and the millennium. Pesantren is a center for people's education and a symbol of the culture of the Indonesian nation itself. And NU (Nabdlatul Ulama') is the only community organization that still maintains the traditional cultural style in pesantren so that the existence of pesantren until now still exists in the archipelago of country along with any diversity in culture and ethnicity.

Santri besides being required to acquire religious knowledge, they are also required to have a good moral personality and manners which will later become a reflection of society. One of the efforts to build the character of students is the recommendation to carry out fasting called dalail Qur'an. The BUQ Gading 
Islamic Boarding School focuses on memorizing the Qur'an, so the fasting ritual that is practiced by the students is the Dalailul Qur'an fasting. It is fasting which is carried out for one year and is obligatory to finish one juz (chapter) in one day during fasting, which the method is reading a holy Qur'an in sequence from chapter (juv) one to thirty, and is repeated from chapter one if the sequence of reading is complete until chapter 30 . There has been quite a lot of research on Dalail fasting. Previously, the study discussed about the Mystical Experience in the Dalail Qur'an as a Countermeasures against the Moral Degradation of Santri (Fitriyah, 2016), the Social and Cultural Role of Islamic Boarding Schools in Shaping the Character of Santri (Kahar et al., 2019), and Subjective Well Being in Fasting Perpetrators of Dalail Al Khairat (Rahmawati \& Jagakarsa, 2018), so in this research, the research discusses the Role of Dalailul Quran Fasting in the Formation of Shoim's Personality.

\section{RESEARCH METHOD}

This study examines the role of dalail fasting on character formation. This research was conducted at the Bustanu Usysyaqil Qur'an Islamic Boarding School (BUQ), Gading, Duren, Kab. Semarang. This type of research is descriptive qualitative research. Qualitative data is all results in the form of description, words, or pictures. The term qualitative research is intended as a type of research whose findings prioritize processes and are not obtained through statistical procedures or other forms of calculation (Sugiono, 2013) such as research on a person's life, history, and behavior, organizational roles, social movements, or reciprocal relationships (Basrowi \& Suwandi, 2008).

The approach used is phenomenological. Data sources are people who are directly involved with pesantren circle. To collect these data, the researcher used several techniques in data collection, such as documentation, the schedule observation of students' activities and interviews with students who practice fasting Dalailul Qura'an, Mu'jiz, the caretaker of the BUQ Gading Islamic boarding school, and also the manager of the BUQ Gading Islamic boarding school. Analysis of the data in the study uses an interpretation pattern. The intended interpretation pattern aims to achieve a correct understanding of facts, data and symptoms. 
JNUS: Journal of Nahdlatul Ulama Studies, Vol. 2, No. 2, Juli 2021: 151-162

\section{DISCUSSION}

\section{BUQ Gading PP Santri's Activities in Shaping Shoim (Fasting) Personality}

The BUQ Gading Islamic Boarding School provides education for santri as well as as a place for recitation of the village community and its surroundings in improving worship procedures, religious activities such as regular Qur'an recitations, participating in routine services such as prayer Tasbih on Friday night in congregation, studying on Saturday nights for villagers, the recitation of Lapanan every Tuesday $W$ age. In addition, there is also a Dalailul Khoirot mujahadah activity which is held every Monday night attended by students and the public generally. There is also a mujahadah every two weeks on Friday nights by reading ya wahhab 1000 times. Both the Tuesday Wage Lapanan recitation activities, the Dalailul Khoirot forum on Monday pon, and mujahadah ya wabhab friday wage, have been running for more than 30 years since the first Islamic boarding school was founded in 1985 ago.

This Islamic boarding school is located in Gading Hamlet, Duren Village, Tengaran District, Kab. Semarang, but is better known as the Salatiga area because its reach is closer to Salatiga than Kab. Semarang. In Gading village, the Serang river is the source of the villagers in society's daily needs and irrigating the fields which are also daily livelihood of the residents. This pesantren is founded by KH. Abdullah Hanif and Mrs. Nyai Anis Thoharoh in 1985 and is now led by Gus Afnan Abdillah. The number of students who are staying is around 250, while the teachers are taught by their sons and daughters-in-law without involving outside educators.

BUQ Gading Islamic Boarding School uses a classical learning system. The classical system is a traditional education pattern that emphasizes the mastery of religious books, which until now this education pattern has been preserved by NU and traditional Islamic boarding schools. In the classical education system, students are required to study the books taught in Islamic boarding schools. The learning process of the classical education system by reading matan, translating and recognizing the meaning contained in it. The focus of learning in the BUQ Gading Islamic Boarding School is Takhfidz, (Memorizing) Quran, so a lot of time and activities are carried out for murojaah, sima'an together, and memorization (undaa'an or ngelob). Based on the recommendation of the salaf scholars that students should carry out riyadhoh fasting to support success, BUQ students are also encouraged to conduct riyadhoh dalalil quran. The Riyadhoh was carried out to achieve the personality character of the santri who are good at controlling themselves in suppressing lust, anger, verbal control for positive words, as well as 
easing the body in eradicating laziness and lightening the body in carrying out activities (Interview with Gus Afnan: 2020). The personality traits mentioned above are Shoim's personalities. Fasting Dalailul Qur'an, apart from aiming to shape the character of shoim, wirid al-Qur'an 1 juz (chapter) per day is a mandatory activity in practicing Dalailul Qur'an fasting which can help facilitate the memorization of students (Interview with Gus Afnan; 2020).

Fasting also relieves the body in activities because energy burning is maximized (Oustric et al., 2020). The educational goal to be achieved by PP BUQ Gading is to produce good and quality student outputs in science and morals. Those are able to control maladaptive behavior that have a negative impact on themselves and the environment, so that they can reflect the values of the Qur'an in the life of students and become a civilized person. Students who are able to control negative behavior will produce good quality students in accordance with the main function of their creation, as servants of Allah ('abd Allah) and as caliphs on earth (khalifah fi al ard). Therefore, the education system of the BUQ Gading Islamic Boarding School tries to reflect the knowledge and behavior of the Prophet Muhammad in everyday life according to the potential and skills of each student.

\section{Dalailul Quran Fasting}

The terms of fasting Dalail Quran comes from the word (لاد) which means

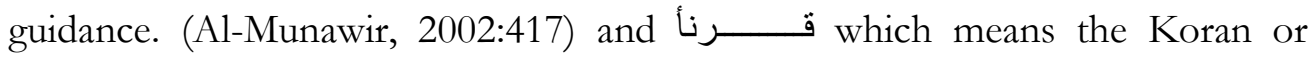
Islamic religious book. The so-called Dalail Quran fasting is an annual fasting (ال دهر) for 1 (year) full accompanied by reading holy Qur'an 30 juz (chapter) every month. (Gus Yasin Interview: 2020). To be able to practice and carry out fasting in the Dalail Quran, the students must go through a process, through getting a diploma and having to get the guidance of a $m u^{\prime} j i$ \%

Fasting Dalail Quran can not be carried out just because of their own desires and carelessness at random. Mu'jiz is a teacher or mentor who gives power and guides students in the implementation of the Dalail Quran fasting starting from the diploma process until the completion of the fasting practice. At the BUQ Gading Islamic Boarding School, the Mu'jiz was KH. Abdullah Hanif as caregiver and founder of the Islamic boarding school, while his previous mu'jiz is $\mathrm{KH}$. Ahmad Basyir Allahuyarmhu from Kudus, and KH. Ahmad Basyir ordered prospective practitioners of the Dalail Quran around Semarang area to the south including Salatiga, Boyolali, Jogjakarta and surrounding areas to submit diplomas to KH. Abdullah Hanif. After passing away of KH. Abdullah Hanif in 2017, the 
JNUS: Journal of Nahdlatul Ulama Studies, Vol. 2, No. 2, Juli 2021: 151-162

Dalail Quran fasting certificate could be obtained through a diploma from his last son, Gus Afnan Abdillah, who had indeed been told to be his successor before he passed away.

The procedure for obtaining the diploma can be directly met with the mu'jir, or in a state of necessity because the reach is very far, for example between countries or between continents, it can be done by telephone. A prospective practitioner frankly wants to ask for and practice the Dalail Quran fasting certificate, then at that time the mu'jiz will ask first "Are you sure you want to practice it?", then if it is surely in certainty, $M u^{\prime} j i z$ will give you a certificate in the form of nyireb fasting as the first mandatory requirement before fasting Dalailul Qur'an. Nyireh fasting is a kind of fasting that is carried out for 7 (seven) consecutive days by not eating or drinking animate materials, such as meat, eggs, milk and the like. This fasting aims to cleanse the heart before carrying out a heavier fast, namely the Dalail Quran (interview, Gus Afnan: 2020).

In the diploma process, the students will be given a sheet of paper by the mu'jiz containing the reading of nyireh fasting and prayers while reading Holy Qur'an for fasting the Dalail Quran, then the students will listen to it and the mu'jiz will read it first, including starting with reading Syahadat completely, afterwards the mu'jiz usually will give certain advice or suggestions related to the practice of fasting the Dalail Quran that will be carried out.

After the diploma process and nyireh fasting are completed, the new students are allowed to carry out the Dalail Quran fasting. This Dalail Quran is carried out for a period of 1 (one) full year continuously and is not allowed to stop even if it is only for one day, except on certain days that are forbidden to fast such as Eid al-Fitr, Eid al-Adha, and Tasyrik on the 11th, 12th, 13th of Dzulhijjah. In one day, it is obligatory to finish 1 chapter (juz), and if in one day, the students miss wiridan 1 chapter (juz) reading the Qur'an, then they must replace it on another day. For female students who are menstruating, they can replace fasting as well as wiridan and read 1 chapter (juz) of $\mathrm{Al}$ Quran on another day, to fulfill the number of fasting days in one year. While in starting this fasting, there are no special provisions, it's just that mu'jiz often gives directions to start it on certain days which are believed in Islam to have virtue in starting activities, months that contain many blessings such as the beginning of the month of Rajab and Muharram, then the count of months that is used as a guide in the implementation of this dalail fasting is not a count of the months of Masebi but uses the Hijria count. For the students of BUQ Gading, on the advice of Gus Afnan to continue the order of his father Kyai Abdullah Hanif Allahuyarhamhu, nyireh fasting began 
on Monday night Tuesday (interview, Gus Afnan: 2020). Ramadan fasting is not included in the calculation of Dalail Quran fasting, so here the students have to add one more month to meet the 1 (one) full year deadline (Kang Masruhan interview: 2020).

There is an additional difference month in fasting Dalail Quran between male students and female students, if it is male students who practice this fasting, the practitioner only needs to add 1 (one) full month of time as a substitute for Ramadan fasting, while female students need to add one month plus to complete menstruation. Although there is a difference in the additional period of fasting, in essence, in practicing the Dalail Quran fasting, the duration is the same, namely 1 (one) year, only for female students who practice their menstruation periods are cut off (interview with Mbak Meli: 2020). The things that must be done by students who practice fasting the Dalailul Quran, for one full year, are to read 1 juz of the Koran every day and within 1 (one) month must complete 30 juz of Holy Qur'an, when detailed then within a period of within 1 year will complete Quran 12 times (interview Kang Maruhan: 2020).

Riyadhoh according to language is an exercise. Meanwhile, according to the term is the practice of continuous self-improvement through dhik $r$ and efforts to get closer to Allah with various kinds of worship. In the study of Sufism, Riyadhoh is the cultivation of the soul, by carrying out worship and subduing the desires of lust (Qusyairiyah, 2005). Therefore, fasting is a form of riyadhoh because there is exercise or mental exercise in addition to holding back hunger but also holding back lust and immoral behavior that leads to personality disintegration. Riyadhah essentially includes moral education and treatment of liver disease so that it will be able to form a good and integrated soul and personality (Nata, 2013).

The reason for calling the Dalail Quran fasting as part of riyadhah is because in its practice a santri must refrain from hunger until the appointed time, quell lust, train himself to leave despicable acts and replace them with commendable actions. In addition, the practitioners are also trained to read Holy Qur'an continuously up to 30 chapters of Qur'an.

Fasting on behalf of Dalail Quran as practiced by these students in a sanad started from Sheikh Abu Abdillah Muhammad Ibn Sulaiman al-Jazuliy al-Simlaliy al-Syarif al-Hasani, Sheikh Muhammad Mahfudz Makah, Sheikh Muhammad Amir bin Idris Pekalongan, Sheikh Muhammadun Pondohan, Sheikh Yasin Jekulo Kudus, KH. Ahmad Basyir Jekulo Kudus, to KH. Abdullah Hanif Kab. Semarang (or better known from Salatiga), then from KH. Abdullah Hanif at the BUQ Gading Islamic Boarding School was confirmed by Gus Afnan. 
JNUS: Journal of Nahdlatul Ulama Studies, Vol. 2, No. 2, Juli 2021: 151-162

\section{The Role of Dalailul Qur'an fasting in the Formation of Shoim's Personality}

Fasting Dalailul Qura'an is recommended for every student who memorizes Holy Qur'an, but students who do not memorize Holy Qur'an are also encouraged to practice fasting Dalailul Qur'an. Something that most motivates students to practice Dalailul Qur'an fasting is because the wisdom of fasting is the formation of a personality that is able to control oneself not to commit immorality, unhelpful behavior, and verbal control not to say bad words, and tend to be more able to hold back an anger (Interview with Kang Farid: 2020). This personality is able to control itself is what Az-Zahrani calls as the shoim personality (Az-Zahrani, 2005). Another form of shoim personality is the ability of students in social interactions, such as eradicating miserliness. The students who practice fasting, sitting together every afternoon waiting for the time to break the fast full of jokes and stories, and eating together in one large container or tray (Interview with Kang Masrukhan: 2020). When the students break their fast together, they share their own food with each other.

Fasting Dalail Quran is a medium of riyadhob for santri, because getting used to hunger to refrain from food will find a spring of wisdom, sharpening the heart easily to accept the light of knowledge in memorizing the Qur'an and, improving personality integrity in the wisdom. After students leave the pesantren, it is hoped that apart from gaining knowledge, they also have good personalities who are able to protect the surrounding community as an application of scientific values in Islamic boarding schools (interview with Mbak Meli: 2020).

Santri practicing fasting Dalail Quran are very rarely subject to indiscipline, more obedient to the rules of Kyai (Interview with Gus Afnan: 2020). The wisdom that appears in the nature of shoim is because people who fast will train to control themselves from immoral acts, and their hearts will be sharpened and easily get divine light, so that their conscience can sensitively feel divine guidance about whatever will be done, and sharpen their intuition and empathy (Az-Zahrani, 2005). In addition, the students are also more diligent in doing and completing the cottage service tasks, and are more empathetic to others, this is due to the habit of breaking the fast together (Interview with Saifudin: 2020). Empathy means that students who fast Dalailul Qur'an have high empathy for other students. This empathy will encourage the students to help each other in the life of the students, of course, because pesantren is a miniature of society on a small scale, the problems of life cannot be separated from interacting life, and it has 
become a social dynamic. This is in line with Venniro's explanation that empathy encourages a person to be introspective in helping others (Venniro \& Golden, 2020).

Santri who practice fasting are generally able to do well with psychological control such as various kinds of disease, and physical control such as doing activities that are forbidden by religion such as stealing, hitting, and ghosob behavior (Interview with Saifudin: 2020). Santri also generally memorize Holy Qur'an in a relatively shorter time than students who do not practice it, and are able to master and practice sciences such as figh and tajwid (Gus Afnan interview: 2020). This happens because, when fasting, the food on body will decrease (Oustric et al., 2020). That way, blood and oxygen levels will be more optimally entering the parts of the human body that need it more, especially the brain. The blood supplied to the digestive tract is reduced for use by other organs, including the brain. Because the brain is the most important organ in the thought process, the brain's performance becomes more maximized (Casanova et al., 2019). This will make it easier for students who practice the Dalailul Qur'an fasting in memorizing Holy Qur'an, it is supported again, that the Dalailul Qur'an fasting practitioners are obliged to do wirid, through reading 1 juz (chpater) per day sequentially from chapter 1 to 30 during 30 days ahead, and students recite the Quran every 30 days. Santri who practice fasting are more diligent in doing wiridwirid, or wiridan (Interview with Mbak Meli, Kang Farid and kang Masrukhan: 2020).

Santri who practice fasting dalail Quran tend to be less likely to engage in behaviors that are detrimental to themselves and others, such as engaging in fights, quarreling, queuing for bathing and buying in cooperatives more patiently, speaking more politely, and being more diligent in night prayers and other prayers (Interview with Mbak Meli: 2020). It can be said that students who practice fasting are better able to resist lust and maladaptive behavior. A full stomach will increase the ability of lust in carrying out maladaptive behavior (Casanova et al., 2019). Among the maladaptive behaviors are procrastination, laziness which then leads to destructive gossiping behavior, heavy feeling of doing worship, as well as other unproductive behavior. As for physically, in the presence of hunger, lust does not have the power to encourage the body to perform maladaptive behavior. Hunger will trigger maximum energy burning, so the body will actually be lighter in carrying out productive activities (Golpour et al., 2014). Therefore, it is rare for students to be sickly because fasting makes their immune system stronger. 
JNUS: Journal of Nahdlatul Ulama Studies, Vol. 2, No. 2, Juli 2021: 151-162

\section{CONCLUSION}

From these results, it can be concluded that:

1. Morally, the habits that arise as a result of fasting, make the practitioners of the Dalailul Quran fasting able to interact well with fellow students, help each other and not be one-sided, erode the stingy nature because when breaking the fast together they share food, and easily adapt to conditions and circumstances. environment so that it does not cause maladaptive behavior, and is open and polite in behaving and speaking generally.

2. Emotionally, students who practice fasting the Dalail Quran can condition and control emotions that normally cannot be controlled properly.

3. In terms of intellectual intelligence, the students who practice fasting Dalail Quran memorize the Qur'an in a relatively shorter time, and are better able to master and practice other sciences besides Holy Qur'an being studied.

4. Spiritually, Dalail Quran fasting practitioners have heart sensitivity to the God, they are more diligent in carrying out night prayers and other wirids.

\section{BIBLIOGRAPHY}

\section{Book References}

Az-Zahrani, M. bin S. (2005). Konseling Terapi (1st ed.). Gema Insani.

Basrowi \& Suwandi. (2008). Memahami Penelitian Kualitatif. Rineka Cipta.

Casanova, N., Finlayson, G., Blundell, J. E., \& Hopkins, M. (2019). Biopsychology

of human appetite-Understanding the excitatory and inhibitory mechanisms of homeostatic control. Current Opinion in Physiology, 12, 33-38. https://doi.org/10.1016/j.cophys.2019.06.007

Fitriyah, A. (2016). MYSTICAL EXPERIENCE DALAIL QUR’'AN SEBAGAI PENANGGULANGAN DEGRADASI MORAL SANTRI. 2, 431-450.

Golpour, im., Mostafazadeh, A., \& Khorasani, H. R. (2014). Holy Quran and hadith perspective on Fasting and immune system. Islam And Health Journal, 1(3), 61-68.

Kahar, S., Barus, M. I., Wijaya, C., Ilmu, T., Babussalam, T., Agama, T., Negeri, I., Natal, M., Islam, M. P., Ilmu, F., Islam, U., \& Sumatera, N. (2019). ANTHROPOS : Jurnal Antropologi Sosial dan Budaya Peran Pesantren dalam Membentuk Karakter Santri. 4(2), 170-178.

Nata, A. (2013). Akhlak Tasawuf dan Karakter Mulia (13th ed.). Rajawali Pers.

Oustric, P., Thivel, D., Dalton, M., Beaulieu, K., Gibbons, C., Hopkins, M., Blundell, J., \& Finlayson, G. (2020). Measuring food preference and reward: 
Application and cross-cultural adaptation of the Leeds Food Preference Questionnaire in human experimental research. Food Quality and Preference, 80, 103824. https://doi.org/10.1016/j.foodqual.2019.103824

Rahmawati, S. W., \& Jagakarsa, U. T. (2018). Subjective Well Being pada Pelaku Puasa Dalail Al Khairat. June 2014.

Sugiono. (2013). Metode Penelitian Pendidikan: Pendekatan Kuantutatif, Kualitatif, dan R\&D. Alfaabeta.

Venniro, M., \& Golden, S. A. (2020). Taking action: Empathy and social interaction in rats. Neuropsychopharmacology, 45(7), 1081-1082. https://doi.org/10.1038/s41386-019-0596-0

Az-Zahrani, M. bin S. (2005). Konseling Terapi (1st ed.). Gema Insani.

Basrowi \& Suwandi. (2008). Memahami Penelitian Kualitatif. Rineka Cipta.

Casanova, N., Finlayson, G., Blundell, J. E., \& Hopkins, M. (2019). Biopsychology of human appetite-Understanding the excitatory and inhibitory mechanisms of homeostatic control. Current Opinion in Physiology, 12, 33-38. https://doi.org/10.1016/j.cophys.2019.06.007

Fitriyah, A. (2016). MYSTICAL EXPERIENCE DALAIL QUR' AN SEBAGAI PENANGGULANGAN DEGRADASI MORAL SANTRI. 2, 431-450.

Golpour, óm., Mostafazadeh, A., \& Khorasani, H. R. (2014). Holy Quran and hadith perspective on Fasting and immune system. Islam And Health Journal, 1(3), 61-68.

Kahar, S., Barus, M. I., Wijaya, C., Ilmu, T., Babussalam, T., Agama, T., Negeri, I., Natal, M., Islam, M. P., Ilmu, F., Islam, U., \& Sumatera, N. (2019). ANTHROPOS : Jurnal Antropologi Sosial dan Budaya Peran Pesantren dalam Membentuk Karakter Santri. 4(2), 170-178.

Nata, A. (2013). Akhlak Tasawuf dan Karakter Mulia (13th ed.). Rajawali Pers.

Oustric, P., Thivel, D., Dalton, M., Beaulieu, K., Gibbons, C., Hopkins, M., Blundell, J., \& Finlayson, G. (2020). Measuring food preference and reward: Application and cross-cultural adaptation of the Leeds Food Preference Questionnaire in human experimental research. Food Quality and Preference, 80, 103824. https://doi.org/10.1016/j.foodqual.2019.103824

Rahmawati, S. W., \& Jagakarsa, U. T. (2018). Subjective Well Being pada Pelaku Puasa Dalail Al Khairat. June 2014.

Sugiono. (2013). Metode Penelitian Pendidikan: Pendekatan Kuantutatif, Kualitatif, dan R\&D. Alfaabeta. 
JNUS: Journal of Nahdlatul Ulama Studies, Vol. 2, No. 2, Juli 2021: 151-162

Venniro, M., \& Golden, S. A. (2020). Taking action: Empathy and social interaction in rats. Neuropsychopharmacology, 45(7), 1081-1082. https://doi.org/10.1038/s41386-019-0596-0

\section{Interview}

Interview with Gus yasin, on May, $11^{\text {st }} 2020$, in Islamic Boarding School BUQ Gading, Duren, Tengaran, Kab. Semarang

Interview with Gus Afnan, on May, 11 2020 , in Islamic Boarding School BUQ Gading, Duren, Tengaran, Kab. Semarang

Interview with Kang masruhan, on May, $12^{\text {st }}$ 2020, in Islamic Boarding School BUQ Gading, Duren, Tengaran, Kab. Semarang

Interview with Mbak Meli, on May, 12 2020 , in Islamic Boarding School BUQ Gading, Duren, Tengaran, Kab. Semarang

Interview with Kang Farid, on May, $19^{\text {st }} 2020$, in Islamic Boarding School BUQ Gading, Duren, Tengaran, Kab. Semarang

Interview with Kang Saifudin, on May, $20^{\text {th }} 2020$, in Islamic Boarding School BUQ Gading, Duren, Tengaran, Kab. Semarang 